\title{
Labour Market Policies and Recruitment in Europe and Italy
}

\author{
Raimondo Ingrassia \\ Department of Economics, Management and Statistics, University of Palermo, Palermo, Italy \\ Email: raimondo.ingrassia@unipa.it
}

How to cite this paper: Ingrassia, R. (2017) Labour Market Policies and Recruitment in Europe and Italy. American Journal of Industrial and Business Management, 7, 1136-1157. https://doi.org/10.4236/ajibm.2017.710082

Received: August 30, 2017

Accepted: October 21, 2017

Published: October 24, 2017

Copyright $\odot 2017$ by author and Scientific Research Publishing Inc. This work is licensed under the Creative Commons Attribution International License (CC BY 4.0).

http://creativecommons.org/licenses/by/4.0/

(c) (i) Open Access

\begin{abstract}
Over the last few years, most studies and labour market policies have focused on the competence of people seeking employment. Few studies have tackled the issue from the point of view of employers and how policy might affect the personnel recruitment. The aim of this article is to try to understand the impact of labour policy on the processes involved in seeking personnel, with specific reference to business organizations. After examining the strategic, organisational and environmental variables that affect the personnel recruitment, the study focuses on analysing active and passive labour policies in Europe and Italy. The results that emerge highlight the fact that labour policy affects certain specific aspects of the personnel recruitment: employee turnover, an individual's employability, outplacement, efficiency of matching between job supply and demand, competitiveness of candidates and their productivity, efficient allocation of job offers, crowding-out effect, degree of selectivity and contingency of search campaigns. The article ends with a few observations regarding the limitations of the study and future research.
\end{abstract}

\section{Keywords}

Human Resource Management, Labour Market Policy, Europe and Italy, Personnel Recruitment, Employers' Search for Employees

\section{Introduction}

Since the 1990s, policy makers have devoted increasing attention to European labour policies for these two main reasons: 1) the need to unify various national policies and converge towards common objectives; 2) the existence of structural imbalances in the EU labour market. These factors have sparked an intense period of policy definition and legislative regulation that has had a major impact on the labour market of EU countries. European labour policies have focused on 
workers' protections and on growth of the job market. The desire for protection has led to protective policies aimed at guaranteeing workers' income through unemployment benefits and social security nets. The desire for growth has given rise to employability policies aimed at increasing professional skills, promoting mobility and guiding decisions regarding human resource allocation on the labour market. Scientific studies have consequently been focused on the supply of available jobs. Few studies have been done, as far as we have ascertained, on employers' behaviour and on how public policies impact their recruitment ${ }^{1}$ [2] [3] [4] [5].

The purpose of this article is therefore to understand the impact of labour policies on recruitment, with a particular focus on the way businesses are organised. To this end, the article is articulated as follows. The second section identifies strategic, organisational and environmental variables that influence personnel searches. Labour policies are a special type of environmental variable. The third section provides a general definition of labour policies, then distinguishing between passive policies and active policies. The fourth section illustrates how labour policies today have evolved from a culture of garantismo (guaranteeing certain rights of the worker) and protectionism to a culture of mobility and flexible security. The fifth and sixth sections give a historical and systematic reconstruction of active policies in Europe and Italy, which are two of the protagonists in this historic moment of European labour-related thought. The seventh section, finally, explains how labour policies affect recruitment. For clarity's sake, the effects of active and passive labour policies are discussed separately, though the two types are intertwined and constitute two sides of the same coin. The final section contains summary considerations on the results of the study, observations on the limits of that study and recommendations for future research.

\section{The Variables That Influence Recruitment}

Recruitment refers both to the decisions made and the actions taken by a company to identify, attract and discover suitable candidates for the vacant positions identified in the business planning process. The goal of an efficient recruitment program is not really to find a large number of candidates in general, but to obtain a reasonable number of candidates consistent with the requisites of the open positions, in a reasonable time frame and in a cost-effective manner. Recruitment is therefore a process that begins by identifying the segments of the labour market where the desired candidates can be found-in this case, we speak of recruitment areas. The next stage of the process is the choice of the most appropriate search channel and the advertising of the vacant positions, and the process ends with a screening of the candidates. Search-related decisions are influenced by three kinds of variables: strategic, organisational and environmental [6] [7] [8] [9] [10].

"It is sufficient to go through the classification used by Eurostat for statistical purposes to demonstrate this almost exclusive focus on supply-oriented policies; a reference to the demand side is found only in the field of employer assistance services for selection and recruitment" [1]. 
Strategic variables. Personnel search programs have different purposes and modalities that depend on the growth strategies pursued by a company during its life cycle to compete on various markets [11] [12] [13] [14]. In the start-up phase, employee searches are aimed at recruiting persons capable of operating in the core business reference model. In small companies, recruitment functions are neglected, or outsourced, if they are indispensable. Of particular interest to the start-up's founder, at least in the European context, are personnel searches in recruitment areas that have arisen as a result of labour policies aimed at supporting the economic development of new businesses through tax incentives for start-ups created by young men and women or through subsidies to self-entrepreneurship. Particularly important at this stage is the company's ability to attract qualified personnel, due to the low appeal the company has on the market and the perception that it is not the ideal place to work [15] [16] [17].

In the development phase, a company can pursue two different strategies: one aimed at internal growth and the other at external growth [6] [18] [19]. The internal growth strategy relies on internal resources (growth in production volumes and sales, product and process innovations, new markets). This phase of the company's life cycle requires finding, transferring or promoting people in sufficient quantity and quality to support the growth and/or diversification strategies of markets or products. In this case, personnel searches target several recruitment areas due to the need to strengthen productive, managerial and staff structures. The external growth strategy tends to avail itself of the collaboration of other organisations through mergers, acquisitions and alliances. Recruitment in this case must address problems deriving from: 1) the need to deal with the staff of other organisations with which the company interacts intensively (problems of developing a common organisational culture) and 2) the need to rationalize new organisational structures in an efficient way (problems of reducing staff and uniting departments and organisational units). Recruitment therefore tends to address a kind of internal labour market, one that arises as a result of the unification of personnel following corporate mergers or to exploit the opportunities created by labour policies in the event of company downsizing (early retirement, outplacement, etc.).

In the mature stage of a company's life cycle, the organisation tends to stabilize its markets and control its operating costs by focusing resources on existing businesses. In such a strategy, the company has an interest in maintaining and retaining existing professional skills, and recruitment processes tend to retrace known paths toward consolidated goals and methods. In this mature phase, the company seeks to keep employee turnover under control to maintain a balanced composition of personnel and thus ensure organisational stability. Policies of staff reduction can be pursued even in the mature phase if motivated by the technological innovation of production processes and the rationalization of organisational arrangements. This results in a company focus on downsizing and managing outbound personnel flows.

In the phase of decline, a company pursues strategies for rationalizing and 
maintaining existing business, but on a smaller scale. Personnel policies in these contexts are influenced by the need to surgically reduce the number of company employees with the goal of retaining the best workers and facilitating the outflow of less useful employees. It is also possible that in these contexts, the reduction of staff is so necessary that management is forced to impose drastic lay-offs, involving even particularly competent and productive members of the workforce. In a crisis situation, the organisation has a strong need to manage the outflows of personnel in a cost-effective and socially responsible way, using tools provided by labour policies (social plans and outplacement agencies, early retirements, income support subsidies and the management of mobility outside the company) [20] [21].

Organisational variables. While the strategic dynamics linked to the company's life cycle affect general recruitment policies, organisational analysis provides detailed information on the professional profiles that must be found. The number and type of job vacancies is determined after carefully analysing the company's needs according to its strategic business plan. Job analysis, job description for the purpose of assignment to a department, person specification and the definition of workloads are management techniques that underlie the definition of open positions on the labour market. The internal labour market, i.e. the set of rules and people operating within a single organisation, should also be considered one of the organisational variables that influence recruitment. The legal and organisational rules governing the internal labour market may influence recruitment through pre-emption rights, obligations to re-hire previously dismissed workers collecting unemployment or mobility benefits, promotions and internal transfers made on grounds of merit or legal conditions [22] [23] [24].

Environmental variables. By environmental variables is meant the set of factors outside a company that are related to the labour market. Some examples are provided as follows. The size and quality of the job supply and demand, the presence of efficient intermediaries, a recruitment culture that privileges traditional channels or direct relationships with the candidate rather than more innovative channels or the intermediation of specialized operators-these are all factors that affect recruitment policies [25]. An excess of lesser qualified candidates requires defensive and selective search campaigns while a shortage of skilled labour would suggest campaigns should be targeted at specific recruitment areas and channels. Efficient intermediaries can induce businesses to outsource parts of the recruitment process.

Political-regulatory variables. Labour policies are a special kind of environmental variable capable of influencing personnel search processes. In democratic societies and advanced economies, the regulation of labour relations is particularly important. We need only consider how employment policies regarding contracts, compulsory and special placement, affirmative action in the field of equal opportunities, retirement, social security and tax relief in favour of particular categories of workers influence employers' recruitment programs and decisions. 


\section{Labour Policies}

Labour policies are a specific area of public policy, that is, part of a set of actions undertaken by public (and private) entities to address a collective problem. We talk about labour policies in the same way we talk about tax, healthcare, economic, infrastructural, scientific and many other policies [26] [27].

In the concept used internationally, labour policies are distinguished into two groups: active and passive policies. The former serve to help people with problems in the labour market (young people, women, ethnic minorities, unemployed persons and people at risk of unemployment, the unemployed who have given up the search for a job, the disabled, the elderly, immigrants, etc.). The latter serve as support to the income of those who are without work or to facilitate those who have a job but wish to leave it. These policies, therefore, are created to help people with work-related problems. This restrictive definition of labour policies was the one adopted by international bodies such as EUROSTAT and OECD until the late 1990s and it inspired parts of the EU document entitled European Employment Strategy (EES) for the five-year period 1998-2002 [28] [29].

However, due to the change in the European socio-economic context and market structure, public labour policies have gradually broadened their scope and widened the sphere of interventions and potential recipients. Since 2003, the EES has begun to deal with more economic issues such as the training of human capital, the adaptation of the job market to technological progress and production needs and ways to help businesses deal with international competitive pressures.

And this is not all. The greater inbound and outbound flexibility in the labour market, the increasing precariousness of employment relationships, the frequent business crises and the critical questioning of stable and highly protected employment relationships are all factors that have contributed to the emergence of a new political culture that no longer sees the labour market as a static meeting between supply and demand, but rather as a series of normal transitions from one job to another. According to what Gazier and Gautié have called Transitional Labour Markets, entering and exiting the labour market is not only due to the involuntary loss of one's job, but also to other physiological circumstances, such as the choice whether to work full-time or part-time, the alternation between work and study, deciding to leave an organisation voluntarily and the free choice of the employer [30] [31] [32].

In this perspective, public policies have had to acknowledge that social conditions have changed and that there is now the need to enhance protections through a different system, called "flexicurity", aimed at combining in the best way possible the flexibility of employment relationships, social security and labour policies. This is a policy that involves low costs and few constraints on leaving a job, the high mobility of workers, generous benefits, the efficiency of public and private services for employment, continuing education and incentives and control over the re-employment of those who receive unemployment benefits. In countries of the European Union, this policy has been implemented with very 
diversified initiatives - in the form of incentives, training, income support, job creation, job search assistance, negotiations between government authorities and various stakeholders and coordination between local and territorial institutions [33] [34] [35] [36].

The framework of labour policies separated into active and passive policies is summarized in Table 1 [37].

The various labour policies are well-summarised in the EUROSTAT documents. The European organisation classifies Labour Market Policy (LMP) into three main categories: services, measures and support. The first categoryservices-covers all activities carried out by Public Employment Services (PES) and other publicly-funded entities, and includes the items: "public and private employment services" and "orientation and job search assistance programs" illustrated in Table 1 . The second category-measures-covers a series of interventions aimed at providing people with new skills and work experience for the pursuit of two purposes: 1) to improve their employability and 2) to encourage employers to create and maintain jobs and hire the unemployed and other target groups. Included in this category are the items "basic and professional training" and all the "incentives" illustrated in Table 1. Finally, the third category-support - covers income integration measures for those who are partially or totally unemployed and measures to fund early retirement. These are measures classified as passive policies [38].

\section{From Passive Policies to Active Labour Policies}

Passive labour policies became established in the European context following the first systemic economic crises of the 1970s. They pursued the dual aim of ensuring the income of workers at risk of unemployment and giving support to

Table 1. Labour policies.

\begin{tabular}{ll}
\hline \multicolumn{1}{c}{ Active labour policies } & \multicolumn{1}{c}{ Passive labour policies } \\
\hline $\begin{array}{l}\text { Measures to encourage demand and } \\
\text { ensure the employability of job seekers }\end{array}$ & $\begin{array}{l}\text { Measures to ensure income support to } \\
\text { individuals in the event of total } \\
\text { or partial loss of employment }\end{array}$ \\
$\begin{array}{l}\text { Incentives for businesses to create } \\
\text { new employment and/or to } \\
\text { maintain existing employment levels }\end{array}$ & $\begin{array}{l}\text { Maintaining the income of the } \\
\text { unemployed, underemployed and people } \\
\text { at risk of unemployment }\end{array}$ \\
$\begin{array}{l}\text { Incentives to hire weaker segments of society } \\
\text { (young people, women, ethnic minorities, } \\
\text { unemployed and people at risk of unemployment, } \\
\text { the unemployed who have given up the search } \\
\text { for a job, the disabled, the elderly, immigrants, etc.) }\end{array}$ & $\begin{array}{l}\text { Early retirement schemes divided into } \\
\text { conditional and non-conditional }\end{array}$ \\
$\begin{array}{l}\text { Incentives for the creation of } \\
\text { businesses and job creation }\end{array}$ \\
$\begin{array}{l}\text { Basic and professional training } \\
\text { Public and private services for employment } \\
\begin{array}{l}\text { Orientation and job search assistance programs } \\
\text { end }\end{array}\end{array}$
\end{tabular}


companies in crisis through subsidies, salary integration, incentives to maintain employment in the company and support for mobility outside the company. Passive policies were configured in Europe according to a model designed to ensure universal coverage of unemployment through general taxation (this is what occurred in France, Germany, the United Kingdom and the Scandinavian countries), with the exception of Italy, which built a fairly corporatist model of protection aimed at ensuring employees [39] [40].

Some examples of passive labour policy measures are outlined in detail in Table 2.

Passive labour policies have by their nature a limited impact on recruitment. In fact, personnel recruitment becomes crucial only during phases of great company initiative, in which the organisation has the need to invest in the development of its own structures in a prospect of growth and consolidation of its business. For this reason, passive policies are generally present in times of crisis, when the company needs to downsize or liquidate business activities to dismiss redundant personnel. For the State, passive policies have always been costly and not very beneficial in terms of rebalancing the labour market, as they do not appear to stimulate much job-seeking in those who benefit from them. After a long period of passive policies, it was understood that the ever-increasing constraints on public budgets and the low level of activation produced by these policies thus required interventions capable of supporting businesses and workers in a perspective of incentivisation, activation and motivation to look for jobs and be re-hired [41].

The joint document of Confindustria and the Labour Unions issued on 1 September 2016 in Italy is testimony to this new awareness [42]. The social partners understood the need to reduce passive policies and strengthen active policies in a national context-these are the words of the document-where: 1) the labour market shows "high unemployment rates, especially among young people, and low employment rates"; 2) there is a need to "govern industrial transition processes" and 3) "recent legislative reforms to social safety nets have considerably reduced the scope of passive labour policies", though a new system of active policies was not yet clearly defined. Active policies, in other words, were considered

Table 2. Passive labour policies.

\begin{tabular}{|c|c|}
\hline Passive labour policies & Measures \\
\hline $\begin{array}{l}\text { Maintaining the income of the } \\
\text { unemployed, underemployed } \\
\text { and people at risk of } \\
\text { unemployment }\end{array}$ & $\begin{array}{l}\text { Partial or full unemployment subsidies-Subsidies } \\
\text { for temporary suspension of work-Subsidies for } \\
\text { underemployment (solidarity contracts) -Compensation } \\
\text { for collective redundancies due to crisis, } \\
\text { business restructuring and bankruptcy }\end{array}$ \\
\hline $\begin{array}{l}\text { Early retirement schemes } \\
\text { divided into conditional and } \\
\text { non-conditional early retirement }\end{array}$ & $\begin{array}{l}\text { Conditional early retirement, that is, with the obligation to } \\
\text { hire resources from among the unemployed and other } \\
\text { social categories-Unconditional early retirement-Early } \\
\text { retirement plans in public administration-Early retirement } \\
\text { plans in the private sector with state-funded incentives in a } \\
\text { framework of agreements between the social partners }\end{array}$ \\
\hline
\end{tabular}


by the social partners as a new way to tackle labour problems in unbalanced and competitive economies.

\section{Active Labour Policies in Europe}

Active labour policies are not new in Europe, but in recent years, they have had gained new impetus in the continent's economical and political context. Active policies have a rather long history that developed in three periods after the Second World War [43].

The first post-war period, dating from the 1950s to the 1960s, featured a few experiences in Sweden based on the doctrines of two trade union economists, Gösta Rehn and Rudolf Meidner. During this period, the labour market, not only in Sweden but also in the rest of Europe, was characterized by shortages in the work force and by recovering economies. The key objective was the development of human capital through training policies and incentives for labour mobility from traditional low productivity sectors to more innovative and growing industry sectors. These policies were very much appreciated by employers who quickly realized that they were faced with an ever-growing need for qualified workers who could fit into modern production processes.

In the second period, from the first half of the 1970s to the early 1980s, the first phenomena of mass unemployment began to appear. The key objective was employment growth. During this period, there was a sharp increase in public-sector employment, while employment in the private sector remained stable; moreover, there was new interest in policies to activate the demand for jobs through job creation initiatives, working with passive policies that could guarantee the income of those who were expelled from production processes.

In the third period, from the second half of the 1990s to the present day, more evolved active policies were defined. For part of this period, there was economic growth in the OECD countries and an excess of labour supply poorly suited to the demand. The key objective became the activation of both labour demand and supply through a system of incentives and employment assistance (guidance and training, tax credits, conditional subsidies, employment services, counselling, job search assistance, etc.).

A comparison between five countries (the UK, Germany, France, Italy and Sweden) in the period 1993-2005 underscores the presence of rather diverse programs, due to the political, institutional and cultural context of the individual states, but all had the objective of increasing people's chances of entering and re-entering the labour market [40].

Table 3 summarizes the framework of active policies in Europe [43].

The first group of policies-incentives-positively or negatively impacts the behaviours of those receiving the incentives. This goal can be achieved in a variety of ways, for example by reducing the size and duration of the benefits, by linking the benefits to participation in certain employment programs or by imposing sanctions. These policies have spread widely throughout Europe and in particular in English-speaking countries [44]. 
Table 3. Active labour policies in Europe.

\begin{tabular}{|c|c|c|}
\hline Active labour policies & Objective & Measures \\
\hline Incentives & $\begin{array}{l}\text { Encourage employment } \\
\text { and discourage } \\
\text { unemployment or } \\
\text { underemployment }\end{array}$ & $\begin{array}{l}\text { Tax receivables-Employment } \\
\text { subsidies-Time limits on receiving } \\
\text { incentives-Reduction of } \\
\text { benefits-Contingent } \\
\text { benefits programs-Sanctions }\end{array}$ \\
\hline Employment services & $\begin{array}{l}\text { Remove obstacles to } \\
\text { employment and facilitate } \\
\text { first entry and/or return } \\
\text { to the labour market }\end{array}$ & $\begin{array}{l}\text { Job brokerage and placement } \\
\text { services-Counselling-Job } \\
\text { search programs-Recruitment } \\
\text { services for businesses }\end{array}$ \\
\hline Employability & $\begin{array}{l}\text { Keeping people who lose their } \\
\text { jobs employable-Minimizing } \\
\text { the depletion of human } \\
\text { capital due to unemployment }\end{array}$ & $\begin{array}{l}\text { Direct job creation in the public } \\
\text { and non-profit sectors-Training } \\
\text { programs not strictly related } \\
\text { to the job that has been lost }\end{array}$ \\
\hline Human capital & $\begin{array}{l}\text { Improve the chance of finding } \\
\text { work by increasing the skills of } \\
\text { those who lose their job }\end{array}$ & $\begin{array}{l}\text { Basic education } \\
\text { (university, language studies, } \\
\text { computer science, etc.) - Vocational } \\
\text { training (apprenticeship, continuing } \\
\text { education, work-study programs, etc.) }\end{array}$ \\
\hline
\end{tabular}

The second group of policies-employment services-is based on measures aimed at removing barriers to employment and facilitating first entry and return to the labour market. These include a series of measures that help people to establish contacts with potential employers. They are especially aimed at the long-term unemployed, to those who have never had a job and to weaker segments of the labour market. They are very common in Scandinavian and English-speaking countries [45] [46].

The third group of policies-employability-is aimed at maintaining working capacity through direct job-creation opportunities in the public and non-profit sectors (social utility workers (LSU) and public utility workers (LPU), mobility from the private sector to the public sector) or participation in training programs not necessarily related to the job that has been lost. These policies were widespread in continental Europe between the 1980s and early 1990s [47] [48] [49].

The fourth group of policies-human capital-aims principally to raise the level of education of those who have had little schooling or are professionally obsolete by intervening with basic education and vocational training. Historically common in Scandinavian countries, they have spread throughout Europe [50].

As mentioned above, the European context today is characterized by policies of flexicurity. These have varied across Europe. In Scandinavian countries, working relationships have had moderate flexibility (few inbound and outbound constraints, reduced working hours, wage flexibility, contractual simplification, mobility outside the company), income support during transition periods and active policies. In the United Kingdom, there has been a high degree of flexibility in working relationships, less social security, but also greater mobility due to more sustained demand. In the countries of continental Europe (France, Germany, the Netherlands), there has been a moderate degree of flexibility and efficient social 
safety nets and active policies. Mediterranean countries have been characterized by widespread forms of flexibility, duality in the labour market (due to unequal job protection mechanisms for different generations and categories of workers) and less effective active policies [51]. The perspective ultimately pursued by flexicurity is to reach a balance of labour policies that minimizes costly passive welfare policies on the one hand and extends cheaper and more empowering active policies on the other ${ }^{2}$ [52].

\section{The Active Labour Policies in Italy}

Active employment policies in Italy have developed over the last twenty years in a series of legislative measures named for their best-known promoters (the Treu Package, the Biagi Reform, the Fornero Reform and the Jobs Act of the Renzi Government).

The Treu Package (Law no. 196/97) was part of a broad decentralization of Italian governmental administration that began with the Bassanini regulations and continued with the reform of Title V of the Constitution [53]. The Treu Law (Legislative Decree no. 469/97) decentralized the functional positioning of the Regions and Provinces, which until then had been centralized and monopolized by the State's national administration, and, more generally, all active labour policies, based on the principle that there can be no effective market management without a proper reading of the professional needs and job demands of the various local territories. Legislative Decree no. 181/2000 introduced some basic principles for the exercise of employment services by the Regions, also establishing a few standards that must be guaranteed by public entities.

The Biagi Reform (Law no. 30/03 and Legislative Decree no. 276/03) introduced further provisions to regulate the organisation of the labour market and intermediation between supply and demand, liberalizing and further decentralizing the implementation of active policies. A few small autonomous measures and other measures in execution of the previous regulations were then put in place, characterizing the following decade up until 2011.

The Fornero Reform (Law no. 92/2012) for the first time established Essential Levels of Performance (LEP) for employment services by intervening on the coordination between active and passive policies. The reform seems to have favoured policies to help the unemployed return to the labour market, but has also shown a certain disinterest for the quality of re-employment of those who receive unemployment benefits [54].

With the Jobs Act of the Renzi Government, it can be said that active labour policies in Italy entered, at least at the formal level, the stage of their maturity (Law no. 183/14). The law and its implementing decrees were intended to ensure

\footnotetext{
${ }^{2}$ In Italy, spending on passive policies still represents the largest share of overall expenditure on labour policies, growing from $€ 20.2$ billion in 2011 to $€ 23.9$ billion in 2012 . Spending on active policies grows for the first time in 2008 (from $€ 4.9$ to 5.6 billion, with an increase percentage-wise of just under 14 percent) but this, however, is mainly due to a growth in employment incentives. In percentage terms, in 2012, the active component of labour policies represented 19 percent of total policies and passive policies stood at 81 percent.
} 
that the benefits of the LEPs were perceived throughout the country and that there was consistent performance of the administrative functions associated with them; to this end, the National Agency for Active Labour Policies (ANPAL) (Legislative Decree no. 150/15) was established and assumed the responsibility for coordination and implementation of policies at the national level [55]. The picture that emerges is illustrated and presented separately for active and passive policies in Table 4 and Table 5.

Table 4. Active labour policies in Italy.

\begin{tabular}{|c|c|}
\hline Active labour policies & Measures \\
\hline Public employment services & $\begin{array}{l}\text { Investments in the establishment and upgrading of the } \\
\text { employment centre system }\end{array}$ \\
\hline $\begin{array}{l}\text { Orientation and individualized } \\
\text { job search assistance }\end{array}$ & $\begin{array}{l}\text { Training programs and assistance in the search } \\
\text { for a first job or a new job }\end{array}$ \\
\hline Professional training & $\begin{array}{l}\text { Training programs to provide the professional } \\
\text { skills required by the labour market }\end{array}$ \\
\hline Incentives for hiring & $\begin{array}{l}\text { Incentives for hiring in the form of social security, } \\
\text { tax and salary-related relief }\end{array}$ \\
\hline $\begin{array}{l}\text { Incentives to making job } \\
\text { positions permanent }\end{array}$ & $\begin{array}{l}\text { Transformation of fixed-term contracts into indefinite-term } \\
\text { contracts in the private sector-Transforming short-term } \\
\text { contracts into long-term contracts in local public agencies, } \\
\text { in public education, hiring social utility workers (LSU) and } \\
\text { public utility workers (LPU) with long-term contracts }\end{array}$ \\
\hline $\begin{array}{l}\text { Incentives to maintain } \\
\text { employment levels }\end{array}$ & $\begin{array}{l}\text { Incentives for hiring people receiving income } \\
\text { supplements or unemployment benefits }\end{array}$ \\
\hline $\begin{array}{l}\text { Benefits at the local level or } \\
\text { regarding specific } \\
\text { professional categories }\end{array}$ & $\begin{array}{l}\text { Incentives for hiring women and persons over } 50 \text { living } \\
\text { in disadvantaged areas or employed in a profession or } \\
\text { in an economic sector characterized by marked gender } \\
\text { disparities-Incentives for employment in Southern Italy }\end{array}$ \\
\hline $\begin{array}{l}\text { Inclusion of disabled people and } \\
\text { other disadvantaged categories }\end{array}$ & $\begin{array}{l}\text { Social security and salary-related benefits or relief } \\
\text { for hiring people with disabilities or in execution } \\
\text { of a court sentence or in prison }\end{array}$ \\
\hline Direct job creation & $\begin{array}{l}\text { Social utility workers (LSU) and public utility workers (LPU) } \\
\text { or mobility from the private sector to the public sector }\end{array}$ \\
\hline Incentives for self-employment & $\begin{array}{l}\text { Incentives for starting a business based on the various } \\
\text { types of target categories (young people, women, } \\
\text { persons over } 50 \text {, disadvantaged categories) }\end{array}$ \\
\hline $\begin{array}{l}\text { Incentives for small businesses } \\
\text { aimed at increasing employment }\end{array}$ & $\begin{array}{l}\text { Incentives for hiring and/or starting a business } \\
\text { envisaged by national and regional legislation }\end{array}$ \\
\hline Equal opportunities & $\begin{array}{l}\text { Positive actions to promote the participation of weaker } \\
\text { segments of society in the labour market (training, access } \\
\text { to employment, careers, inclusion in certain work sectors) }\end{array}$ \\
\hline Continuous training & $\begin{array}{l}\text { Financing business, sectoral and individual training plans } \\
\text { and "vouchers" provided by the Regions pursuant to } \\
\text { Art. } 9 \text { of Law no. } 236 / 93 \text { and Art. } 6 \text { of Law no. } 53 / 00\end{array}$ \\
\hline $\begin{array}{l}\text { Implementation of educational } \\
\text { and professional training } \\
\text { obligations }\end{array}$ & $\begin{array}{l}\text { Funding programs for compulsory education through } \\
\text { the school system, vocational training and apprenticeship } \\
\text { (Article } 68 \text {, Law no. } 144 / 99 \text { ) }\end{array}$ \\
\hline European Social Fund (ESF) & $\begin{array}{l}\text { Systematic actions in the field of training and education } \\
\text { Actions in the field of education co-funded by the ESF }\end{array}$ \\
\hline
\end{tabular}


Table 5. Passive labour policies in Italy.

\begin{tabular}{ll}
\hline Passive labour policies & \multicolumn{1}{c}{ Measures } \\
\hline Unemployment benefits & $\begin{array}{l}\text { Income supplements to persons partially or totally suspended } \\
\text { from employment (classified in Italy as CIG, CIGS) } \\
\text { or unemployed (NASPI, ASDI, etc.) }\end{array}$ \\
& $\begin{array}{l}\text { Early retirement measures contingent on the hiring of } \\
\text { unemployed persons and other social categories-Unconditional } \\
\text { early retirement measures-Early retirement plans in the } \\
\text { Public Administration-State-sponsored early retirement } \\
\text { plans in the private sector in a framework of } \\
\text { agreements between the social partners }\end{array}$ \\
&
\end{tabular}

As can be seen, Italian labour policies are formally in line with European policies, as they are subject to convergence with EU standards due to common economic policy and statistical harmonisation. There are, however, elements of divergence with the best European experiences due mainly to two factors: spending on active policies and the organisation of employment services [56].

With regard to spending, the share of Italian GDP spent on these policies in the period 1996-2011 has always been lower than the European average, with marked differences between Italy and the Scandinavian and continental European countries. The distance from the European averages is, however, considerably less if the item "expenditure on employment services" is excluded. That is to say that while spending on active policies in Italy is lower, but not much lower, than the European average, spending on the implementation of these policies is indeed quite far from European standards [57].

With regard to the organisation of employment services, the inadequacy of employment services is consistent with the underfunding of the implementation policies. Moreover, professionalism, performance evaluation systems and skills allocation appear inadequate to the proposed labour policy objectives. The professional skills required to implement active policies are more highly qualified, entrepreneurial and creative than the bureaucratic administrative skills used to put passive policies to work. This demand for new professional skills would require incisive re-qualification and training of staff and a different approach to the demand for jobs, and this is decisive for the success of active policies [58]. Employment Centres should also be evaluated on the basis of the precise performance indicators established by the Jobs Act, such as the reduction in the average length of unemployment, service delivery times and the amount of intermediation in bringing together job supply and demand. And finally, as far as the allocation of duties is concerned, it is worth recalling that before the Fornero and Renzi reforms, a very decentralized model of active policy implementation was used, in which the Regions were the principal actors. However, the Regions proved to be ineffective in coordinating labour policies due to a certain disinterest in reducing spending on subsidies and social safety nets so as to increase spending for active policies, for the sole reason that in the Italian system, passive 
spending is supported by the central government and not by the Regions. This organisational scheme should be altered in the direction of unitary coordination and the empowerment of regional structures, as has been implemented for years in countries such as France, Germany and the United Kingdom, where coordination between active and passive policies has worked best [59] [60].

\section{The Impact of Labour Policies on Recruitment}

The distinction between active and passive work policies is now coming under scrutiny, as we have seen in the previous pages, and labour policies tend to be viewed as a unitary interplay of measures in a broader perspective of flexicurity. For the sake of clarity, however, we consider it useful to maintain this distinction in order to examine in greater detail the effects that labour policies produce on recruitment.

\subsection{The Impact of Passive Policies}

Passive policies have a highly unique impact on recruitment. In principle, they are policies designed to protect the income of employers in times of business contraction, when the company has an interest in favouring the outflow of staff. For this reason, the passive policies that have the greatest impact on recruitment are those related to early retirement, unemployment benefits and outplacement.

Employee turnover. One way to reduce redundancies, commonly used in certain political circumstances (social pressure), legislative circumstances (permissive regulations) and business circumstances (high average age of staff, mergers and acquisitions, re-engineering, downsizing, etc.), is early retirement. Early retirement measures may range from specific measures in favour of certain categories of workers and/or enterprises-for the purpose of supplementing any missing social security contributions at the expense of the State or private parties-to the obligatory creation of so-called "solidarity funds" by the social partners $^{3}$ [61] [62].

Early retirement measures may be provided in the form of obligations or incentives to protect workers who are dismissed by the company but who are still young enough to seek full-time employment or to encourage the replacement of older workers with other categories (young people, minorities, workers collecting mobility benefits, protected categories, etc. $)^{4}$ [63]. Early retirement plans

\footnotetext{
${ }^{3}$ Let us highlight two cases. The Montepaschi di Siena (MPS) redundancy plan, which calls for a transition from 25,200 workers (full time equivalents) in 2016 to 22,600 in $2019(\Delta=2,600)$. Of these, 2,450 should go into early retirement with the support of the banking sector's "solidarity" fund, 450 due to normal employee turnover and 300 new people should be hired. Telecom Italia's redundancy plan for voluntary early retirement (pursuant to Article 4 of the Fornero Law). On the basis of current legislation, the trade unions have agreed that the company will pay, monthly, through the national social security institute (INPS) and for the next four years, the pension accrued at the time of leaving based on the worker's social security contributions.

${ }^{4}$ Bill no. 700/08, proposed by Senator Giorgio Roilo, provided for measures to re-hire over 45 workers through incentives in the form of tax relief, tax credits, deductions from taxable income and professional redeployment initiatives.
} 
affect employee turnover. On the one hand, the employer benefits from these kinds of measures as they reduce the cost of labour and enhance the income statement. Moreover, incentives may be established to encourage the replacement of retiring staff with equivalent but less economically-demanding workers, for example when firms tend to hire low-paid young people and reduce the number of older workers with higher labour costs.

Employability. Unemployment benefits are policy measures that have been pursued and practised in Europe since States began to bear the burden of the economic and social damage caused by recurring business crises. A system of social safety nets establishes measures to maintain the income of people who are unemployed, underemployed or at risk of losing their jobs in all European countries. In Italy (and elsewhere), these policies have over time assumed diversified forms of income support (CIG, CIGS and in derogation, "solidarity" funds and contracts), mobility outside the company and unemployment benefits (NASPI, ASDI). Passive policies impact recruitment processes when rules are in place that establish recruitment priorities and obligations to re-hire workers receiving lay-off benefits or mobility allowances. They also impact recruitment to the extent they are accompanied by interventions aimed at promoting the reintegration of people into the labour market. In Italy, both the Fornero Reform and the Jobs Act have moved in this direction. The Fornero Reform introduced New Unemployment Aid Instruments (ASPI) with the aim of strengthening the links between economic protection and policies to favour the activation of unemployed people 5 .

The Jobs Act introduced new rules to the labour market based on the principles of active policies, among which we find: 1) a clear distinction between income support and unemployment benefits; 2) the level and duration of subsidies proportionate to the seniority of the worker; 3 ) support in moving from one job to another through intensive and personal assistance. The reforms' impetus towards active policies pursues the goal of creating employability, that is, a person's readiness to work on the labour market. Employers can only benefit from these policies, as they will lead them to interact with candidates who are in principle well-oriented job-seekers who are aware of their skills, economically motivated and professionally up-to-date. In other words, employable [64].

Outplacement. The Decree implementing the Jobs Act of 20 February 2015 in Italy introduced provisions for outplacement contracts. This regulation facilitates the reintegration of dismissed workers or workers at risk of unemployment through a process that involves: analysis of the employability of the person, participation in vocational training and retraining programs, attribution of a financial sum in the form of a voucher, intensive assistance in seeking new employment and the acceptance of professionally- and economically-suited job offers in line with the person's work history [65].

${ }^{5}$ Meaning of acronyms: CIG (Temporary Unemployment Compensation). CIGS (Extraordinary Temporary Unemployment Compensation. NASPI (New Social Insurance for Employment). ASDI (Unemployment Benefit). 
In Europe, recruitment assistance policies have long been at work in countries such as France, Germany, Belgium, the Netherlands, Spain and Scandinavian countries, albeit with very different rules and procedures, which include financial aid, facilities and services in support of businesses and workers, the active involvement and empowerment of employers and workers, preventive redeployment actions designed to anticipate business crises, public service experiments and the concerted participation of different stakeholders (local authorities, employment centres, training bodies, private labour agencies, employers' and trade unions) [66].

Available data from the AISO show a substantially stable redeployment market with few variations over the years. From 2008 to 2015, the average number of redeployed workers was around 6577, of an average total of 8000 people assisted per year, with a rate and average relocation time of $82 \%$ and 6 months, respectively [67]. This trend could begin to grow thanks to recent legislative action, greater awareness of the law, the new attitude of the social partners towards active policies and a general framework aimed at disincentives for passive policies.

There are various effects of outplacement on recruitment. A survey by ACF-Europe, conducted on a sample of almost 100 decision makers working in the field of human resources in Germany, has identified three significant effects: 1) avoiding legal action related to company downsizing plans; 2) giving a sign of social responsibility to the employees who remain in the company; 3) giving dismissed workers a demonstration of fairness [68]. But there are also others: 4) the presence of incentives and concessions to employers who hire workers registered in mobility, unemployed or income support lists and enrolled in outplacement programs; 5) programs to actively assist workers expelled from production processes before retirement age to remain employed until they reach that $a^{6} e^{6}$; 6) the assisted management of company employee turnover; 7) increasing or maintaining employer branding in the labour market; 8) managing the company's redundancy at lower net costs; 9) better relations with stakeholders (trade unions, local administrations and communities); 10) flexibility in staff sizing policies ${ }^{7}$.

\subsection{The Impact of Active Policies}

There are not many studies on the impact of active policies on recruitment in the literature. The study of Calmfors et al. based on the Swedish political and economic experience is particularly interesting for this article [69]. The effects that active policies have on recruitment are identified by those authors as follows.

${ }^{6}$ The agreement dated 17 May 2010 between ABI (Italian Banking Association) and AISO (Italian Outplacement Society Association) provided for professional redeployment services for redundant workers in the banking sector.

${ }^{7}$ Law no. 223/91 (art. 5, par. 5) for example, as opposed to other countries in Europe, imposed lower redundancy costs on Italian employers who reduced staff and made use of redundancy redeployment initiatives. The Fornero Reform of 2012 cancelled this favourable norm, which the Jobs Act then restored. 
Efficient matching of supply and demand. Active policies related to employment services produce a more efficient matching of job supply and demand in terms of timing and the quality of the parties involved. The participation of job seekers in labour market training and search programs, the strengthening of the role of agencies and company recruitment services all favour, in principle, the mutual knowledge and awareness of the employers and applicants. In an efficient system of intermediation, the employer may be motivated to publicize vacant positions so as to minimize the use of informal search channels that do not always provide the best results in terms of the qualifications of the person hired $^{8}[25]$. Accelerated matching of supply and demand and the publicizing of vacancies will also help fast-growing companies to find the people they need quickly, and in the quantity and of the quality suitable to the production processes to be carried out [70].

Competition between candidates. Active policies aimed at increasing employability and human capital encourage participation in the labour market and increase competition among the candidates as more and more prepared and up-to-date people compete for a constant number of vacant positions. In tight labour markets, the competition effect might play a lesser role. It has been found that policies aimed at increasing employability are more suitable in areas where the number of vacant positions is increasing than in those where higher unemployment rates are present.

More productive job seekers. Active policies based on human capital formation tend to increase the potential productivity of job seekers. This could affect the minimum acceptable salary of candidates who are aware of their greater production capacity and could increase their economic demands by raising the amount below which they would no longer be willing to accept a job proposal.

Efficient allocation of job offers. The first active employment policies in Sweden were aimed at promoting the mobility of a small workforce from declining industrial sectors with low productivity to growing and high-productivity sectors. In the presence of policies aimed at stimulating inter-sectoral mobility, employers in growing and driving sectors will find themselves with a higher number of job candidates and, inevitably, a diminished impact on minimum acceptable salaries (which may tend to diminish) and potential productivity (which could increase as a result of good training), while firms in declining sectors tend to find difficulties in filling job positions.

Crowding-out effect. As in all business initiatives induced by economic and regulatory benefits, incentives can disrupt the regular labour demand-that which would exist when an employer is in need of personnel for his/her production

\footnotetext{
${ }^{8}$ According to data from the Excelsior survey conducted on 100,000 Italian companies, the direct knowledge of candidates was appreciated by companies in general, growing $9.7 \%$ between 2010 and 2014. The most noticeable decline regarded the channel "reporting acquaintances and suppliers", which decreased from $11.9 \%$ in 2010 to $6 \%$ today. The use of specialized operators also decreased, down from $8.5 \%$ to $6.1 \%$ in the same period (though it tends to increase significantly in proportion to the size of the company), as did traditional channels such as printed advertisements. This is a sign of the still common lack of trust in public and private intermediaries.
} 
needs and there are no incentives for hiring. An incentive-based work policy can distort normal company recruitment processes. Therefore, thorough attention is required of employers and policy makers. The former should assess whether their business is economically viable even in the absence of those incentives. The second should assess whether incentive-based employment policies can truly stimulate entrepreneurial activity and long-term productive investment in a given territory.

More selective and more contingent search campaigns. Active policies provide for incentives to hire particular categories of people (classified according to age, place of residence, gender, ethnicity, professional characteristics, personal circumstances, etc.) with no limits placed on the time and place. Recruitment incentives affect business decisions, as business always pay great attention to ways to reduce labour costs. Given a certain framework of incentives, personnel search campaigns must become more targeted and selective in order to use information and channels that make it possible to contact a large number of potential beneficiaries. Consider, also, that certain people with certain socio-demographic and professional characteristics-young people, unemployment benefit recipients, graduates-need to be registered with accredited public or private programs or agencies in order to be hired, otherwise certain incentives are not applicable ${ }^{9}[71]$.

\section{Conclusions and Future Research}

Labour policies in Europe and Italy now generate more selective and transparent recruitment processes than in the past because they must take into account the impact, constraints and induced opportunities created by the many different policy measures. They are more selective because the range of labour policies requires the capacity to discern and classify different categories of desired candidates in the light of the administrative measures involved. They are more transparent because the measures themselves may require a certain degree of formalization of recruitment initiatives, such as the advertising of vacant positions with certain contractual conditions, the mandatory registration with public and private intermediaries and the disclosure of business data and projects to public authorities to obtain access to the measures. The employer, therefore, must be prepared to establish priorities and make evaluations and contingent choices during the recruitment process. This renders the employee search process more critical and requires more sophisticated professional skills on the

${ }^{9}$ To get an idea of the maze of employment incentives in Italy, see the Anpal Guide. It is a 79-page document continuously updated by the Agency. The guide attempts to orient workers in the jungle of employment incentives throughout the country. The intervention areas are: (1) the incentives to hire and set up a business based on of the type of recipients; (2) the incentives provided by the national programs of ANPAL-Servizi Spa (formerly Italia-Lavoro Spa) carried out in collaboration with the Regions and Autonomous Provinces; (3) the incentives for hiring and new enterprise provided for by regional laws; (4) notices and tenders by the Regions and Autonomous Provinces for incentives funded by the European Social Fund and by the European Regional Development Fund 2014-2020. 
recruiter's part.

In this context, scientific research should focus on exploring the relationships between specific measures and their effects on personnel search decisions using a wide range of empirical survey instruments such as employer opinion surveys, actual search behaviour statistics, interviews with human resource managers, thematic focus groups and rigorous methods to analyse the impact of regulation. The limits of this study can be found in the pioneering nature of the topic itself. As we noted in the introduction, few studies have been carried out on how labour policies impact the behaviour of companies in their recruitment. A great deal of empirical and theoretical research remains to be done on a subject that is crucial for the success of new labour policies.

\section{References}

[1] CNEL (National Economy and Labour Council) (2014) Rapportosulmercato del lavoro 2013-2014. Market Labour Report, 198, Note 56. http://www.cnel.it

[2] Marocco, M. (2013) La doppia anima dellepoliticheattive del lavoro e la RiformaFornero. [The Dual Soul of Active Labour Policies and Fornero Reform.] WP-CSDLE “Massimo D'Antona”, 2, 1-35. http://csdle.lex.unict.it/workingpapers.aspx

[3] Gore, T. (2005) Extending Employability or Solving Employers' Recruitment Problems? Demand-Led Approaches as an Instrument of Labour Market Policy. Urban Studies, 42, 341-353. https://doi.org/10.1080/0042098042000316182

[4] Ingrassia, R. (2016) Jobseeking Behaviour Theory: Le implicazioni per idatori di lavoro e loroprocessi di reclutamento. [Job-Seeking Behaviour Theory: Implications for Employers and Their Recruitment Processes.] Annalidella Facoltà di Economia, LXIX-LXX, 55-87.

[5] Spoonley, P. (2008) Utilising a Demand-Led Approach in a Local Labour Market. Local Economy, 23, 19-30. https://doi.org/10.1080/19401490801906536

[6] Noe, R.A., Hollenbeck, J.R., Gerhart, B. and Wright, P.M. (2010) Human Resource Management. 7th Edition, MacGraw-Hill, Chicago.

[7] Costa, G. and Gianecchini, M. (2013) Risorse Umane. [Human Resource.] MacGraw-Hill, Milano, 181-204.

[8] Zerilli, A. (2002) Reclutamento, selezione e accoglimento del personale. [Recruitment, Selection and Onboarding of Staff.] Franco Angeli, Milano, 17.

[9] Galluzzi, R. and Sala, E. (2009) La selezione: dagli Yes Men aitalenti. [Recruitment: from Yes Men to the Truly Talented.] In: Boldizzoni, D., Ed., Management dellerisorseumane [Human Resource Management], Il Sole 24 Ore, Milano, 65.

[10] Dessler, G. (2015) Fundamentals of Human Resource Management. 4th Edition, Global Edition, Pearson International.

[11] Schuler, R. and Jackson, S. (1987) Linking Competitive Strategies with Human Resource Management Practices. Academy of Management Executive, 1, 207-219. https://doi.org/10.5465/AME.1987.4275740

[12] Rutherford, M.W., Buller, P.F. and McMullen, P.R. (2003) Human Resource Management Problems over the Life Cycle of Small to Medium-Sized Firms. Human Resource Management, 42, 321-335. https://doi.org/10.1002/hrm.10093

[13] Tam, S. and Gray, D.E. (2016) What Can We Learn from the Organizational Life Cycle Theory? A Conceptualization for the Practice of Workplace Learning. Journal of Management Research, 8, 18-30. https://doi.org/10.5296/jmr.v8i2.9093 
[14] Baird, L. and Meshoulam, I. (1988) Managing Two Fits of Strategic Human Resource Management. Academy of Management Review, 13, 116-128.

[15] Williamson, I.O. (2000) Employer Legitimacy and Recruitment Success in Small Businesses. Entrepreneurship: Theory and Practice, 25, 27-43.

[16] Cardon, M.S. and Stevens, C.E. (2004) Managing Human Resources in Small Organizations: What Do We Know? Human Resource Management Review, 14, 295-323. https://doi.org/10.1016/j.hrmr.2004.06.001

[17] Abraham, M., Kaliannan, M., Mohan, A.V. and Thomas, S. (2014) A Review of SMEs Recruitment and Selections Dilemma: Finding a Fit. The Journal of Developing Areas, 12, 1-17.

[18] Tanova, C. (2003) Firm Size and Recruitment: Staffing Practices in Small and Large Organisations in North Cyprus. Career Development International, 8, 107-114. https://doi.org/10.1108/13620430310465534

[19] DeVaro, J. (2005) Employer Recruitment Strategies and the Labour Market Outcomes of New Hires. http://digitalcommons.ilr.cornell.edu/articles/106/

[20] Daft, R. (2013) Organization Theory and Design. Cengage Learning, South West.

[21] Cascio, W.F. and Wynn, P. (2004) Managing a Downsizing Process. Human Resource Management, 43, 425-436. https://doi.org/10.1002/hrm.20034

[22] Windolf, P. (1986) Recruitment, Selection, and Internal Labour Markets in Britain and Germany. Organization Studies, 7, 235-254. https://doi.org/10.1177/017084068600700302

[23] Adams, J., Greig, M. and MacQuaid, R.W. (2000) Mismatch Unemployment and Local Labour-Market Efficiency: The Role of Employer and Vacancy Characteristics. Environment and Planning, 32, 1841-1856. https://doi.org/10.1068/a3342

[24] Osterman, P. (1987) Choice of Employment System in Internal Labour Market. Industrial Relation, 26, 46-67.

[25] Excelsior (2015) La domanda di professioni e di formazionedelle imprese italiane. [The Professional Skills and Training Required by Italian Firms.] Unioncamere-Ministero del Lavoro, Sistema Informativo Excelsior, Roma.

[26] Howlet, M. and Ramesh, M. (1995) Studying Public Policy: Policy Cycle and Policy Subsystems. Oxford University Press, Toronto.

[27] Martini, A. and Sisti, M. (2012) Valutare il successo delle politiche pubbliche. [Evaluating the Success of Public Policies.] Il Mulino, Bologna, 23.

[28] ISFOL (2008) Diecianni di orientamentieuropei per l'occupazione (1997-2007). [Ten Years of European Employment Guidelines.] Rubbettino, Catanzaro, 157.

[29] ISFOL (2014) Rapporto di monitoraggio del mercato del lavoroitaliano. [Italian Labour Market Monitoring Report.] I Libri del FondoSocialeEuropeo, Roma, 13.

[30] Gazier, B. and Gautié, J. (2009) The Transitional Labour Markets Approach: Theory, History and Future Research Agenda. Document de Travail du Centre d'Economie de la Sorbonne. http://ces.univ-paris1.fr/cesdp/CES-docs.htm

[31] Treu, T. (2013) Le istituzioni del lavoronella Europa dellacrisi. [Work Institutions in Europe during the Economic Crisis.] Giornale di Diritto del Lavoro e di Relazioni Industriali, 4, 140.

[32] Schmid, G. (1998) Transitional Labour Markets: A New European Employment Strategy. Discussion-Paper (FS), I, 98-206. Wissenschaftszentrum Berlin für Sozialforschung.

[33] Ichino, P. (2015) Il lavororitrovato. [Finding a New Job.] Mondadori, Milano, 27. 
[34] Pombeni, M.L. (2010) L'orientamento professionale. [Vocational Orientation.] In: Argentero, P., Cortese, C.G. and Piccardo, C., Eds., Psicologia delle risorse umane [Human Resource Psychology], Raffello Cortina Editore, Milano, 69.

[35] Grandori, A. (2015) 10 Tesisull'impresa. [10 Thesis on Business.] Il Mulino, Bologna, 69.

[36] Wilthagen, T. and Tros, F. (2004) The Concept of Flexicurity: A New Approach to Regulating Employment and Labour Markets, Transfer. European Review of Labour and Research, 10, 2. https://doi.org/10.1177/102425890401000204

[37] ISFOL (2008) Diecianni di orientamentieuropei per l'occupazione (1997-2007). [Ten Years of European Employment Guidelines.] Rubbettino, Catanzaro, 215-220.

[38] Ronkowski, P. (2013) Labour Market Policy Expenditure and the Structure of Unemployment. Eurostat. Statistics in Focus.

http://ec.europa.eu/eurostat/statistics-explained/index.php?title=Archive:Labour_m arket_policy_expenditure\&oldid $=238577$

[39] Esping-Anderson, G. (1990) The Three Worlds of Welfare Capitalism. Princeton University Press, Princeton, NJ.

[40] Giubileo, F. (2011) Uno o piùmodelli di politiche del lavoro in Europa? I servizi al lavoro in Italia, Germania, Francia, Svezia e Regno Unito. [One or More Models of Labour Policies in Europe? Work Services in Italy, Germany, France, Sweden and the United Kingdom.] Rivista del Dirittodella Sicurezza Sociale, XI, 759-777.

[41] Treu, T. (2012) Flessibilità e tutelenellariforma del lavoro. [Flexibility and Protection in Job Reform.] WP-CSDLE “Massimo D’Antona”, IT, 155, 1-62. http://csdle.lex.unict.it/workingpapers.aspx

[42] Confindustria, CGIL, CISL and UIL (2016) Proposte per le politiche del lavoro (Proposals for labour policies), 1-7. Text available at: http://www.cisl.it/

[43] Bonoli, G. (2010) The Political Economy of Active Labour Market Policy. REC-WP, 1, 1-29. Working Papers on the Reconciliation of Work and Welfare in Europe, Edinburgh. http://www.sps.ed.ac.uk

[44] Peck, J. (2001) Workfare States. Guildford Press, New York.

[45] Van Berkel, R., Casswell, D., Kupka, P. and Larsen, F. (2017) Frontline Delivery of Welfare-to-Work Policies in Europe. Routledge, New York.

[46] Sartori A. (2013) Servizi per l'impiego e politichedell'occupazione in Europa. Idee e modelli per l'Italia. [Employment Services and Employment Policy in Europe. Ideas and Models for Italy.] Maggioli, Rimini.

[47] Forrier, A. and Sels, L. (2003) The Concept Employability: A Complex Mosaic. Human Resources Development and Management, 3, 102-124. https://doi.org/10.1504/IJHRDM.2003.002414

[48] McQuaid, R.W. and Lindsay, C. (2005) The Concept of Employability. Urban Studies, 42, 197-219. https://doi.org/10.1080/0042098042000316100

[49] Sommer, J. and Rosenthal P. (2012) Active Labour Market Policy and Direct Job Creation in Germany: Achievements, Challenges, and Pitfalls. Local Economy, 27, 494-501. https://doi.org/10.1177/0269094212445536

[50] Manzolini, L. (1984) Economia e organizzazione delle transazioni di lavoro in impresa. [Economics and Organization of Labour Relations in Business.] Giuffrè, Milano, 15.

[51] Reyneri, E. (2011) Sociologia del mercato del lavoro. [Labour Market Sociology.] Il Mulino, Bologna, 144. 
[52] Alaimo, A. (2015) Ricollocazione dei disoccupati e politicheattive del lavoro. Promesse e premesse di security nel Job Act del Governo Renzi. [Relocation of Unemployed Workers and Active Labour Policies. Promises and Job Security Premises in the Renzi Government's Jobs Act.] WP-CSDLE “Massimo D’Antona”, 249, 1-24, Note 13.

[53] FORMEZ (2012) Osservatorisulmercato del lavoro locale. [Local Labour Markets Reports.] Cangemi, Roma.

[54] Ales, E. (2012) The Italian Reform of the Labour Market in a Growth Perspective. European Labour Law Journal, 3, 70-85. https://doi.org/10.1177/201395251200300106

[55] Garilli, A. (2014) Occupazione e diritto del lavoro. Le politiche del lavoro del governo Renzi. [Employment and Labor Law. The Policies of the Government of Renzi.] WP-CSDLE“Massimo D’Antona”, 226, 1-17. http://www.csdle.lex.unict.it

[56] ISFOL (2008) Diecianni di orientamentieuropei per l'occupazione (1997-2007). [Ten Years of European Employment Guidelines.] Rubbettino, Catanzaro, 216.

[57] ISFOL (2016) I canali di intermediazione e iservizi per illavoro. [Intermediaries and Job Services.] Collana Research Paper, 31, 52. http://www.isfol.it

[58] Giubileo, F. and Marocco, M. (2012) Servizi per l'impiego, non bastanoilivelliessenziali. [Basic Employment Services Are Not Enough.] http://www.lavoce.it

[59] Dell'Aringa C. (2016) Le politicheattive del lavoronellariforma. [Active Labour Policies in Reform.] NuoviLavori, 180, 1-3. http://www.nuovi-lavori.it/

[60] Fava, G. (2017) Politicheattive del lavoro. Il punto ad oggi. [Active Labour Policies. The Current Situation.] Direzione del Personale, 180, 56-58.

[61] Casadei, C. Tagliati 2600 dipendenti, sarannoaccantonati 550 milioni (2,600 workers dismissed, 550 million euros allocated). Il Sole24Ore of 26 October 2016.

[62] Telecom Spa (2016) Assemblea in data 25 maggio 2016. Domande pre-assembleari (Shareholders' Meeting on May 25, 2016. Pre-Meeting Questions), 1-21. Text available at: http://www.telecomitalia.com

[63] Treu, T., Ed. (2013) Employability per persone e imprese. Percorsi di outplacement. [Employability for People and Businesses. Outplacement Paths.] Guerini e Associati, Milano, 93.

[64] Bollérot, P. (2002) Labour Shortages and Employability: A European and International Approach. International Social Security Review, 55, 19-38. https://doi.org/10.1111/1468-246X.00130

[65] INTOO (2011) Outplacement. Testimonianze e Prospettive. [Outplacement. Testimonies and Perspectives.] Panorama Economy, Milano.

[66] Varesi, P. and Fagnoni, S. (2013) Responsabilizzazione dell'impresa nei processi di ricollocazione del personale eccedente. [Business Responsibility in the Redundant Staff Relocation Processes.] In: Treu, T., Ed., Employability per persone e imprese. Percorsi di outplacement [Employability for People and Businesses. Outplacement Paths], Guerini e Associati, Milano.

[67] http://www.aiso-outplacement.it

[68] Association of Career Firms Europe (ACF-Europe), Survey (2016) HR Decision Makers Value Outplacement Services: Motives, Expectations and Trends. http://www.acf-europe.org

[69] Calmfors, L., Forslund, A. and Hemstrom, M. (2001) Does Active Labour Market Policy Work? Lesson from the Swedish Experiences. Swedish Economic Policy Review, 85, 61-124. 
[70] Mortensen, D. and Pissarides, C. (1994) Job Creation and Job Destruction in the Theory of Unemployment. The Review of Economic Studies, 61, 397-415. https://doi.org/10.2307/2297896

[71] ANPAL (2017) Guida Incentivi alle assunzioni e allacreazioned'impresa. [Incentives Guide to Hiring and the Creation of Enterprise.] http://www.anpal.gov.it 